This is a revised personal version of the text of the final journal article, which is made available for scholarly purposes only, in accordance with the journal's author permissions. The full citation is:

Zhang, S., C. J. Banks, S. Heaven, and A. M. Salter. "Operation and recovery of a seasonally-loaded UK waste stabilisation pond system." Water Science \& Technology 67, no. 5 (2013): 1105-1112.

doi:10.2166/wst.2013.657, http://www.iwaponline.com/wst/06705/wst067051105.htm

\title{
Operation and recovery of a seasonally-loaded UK waste stabilisation pond system
}

\author{
S. Zhang, C.J. Banks, S. Heaven and A.M. Salter
}

Faculty of Engineering \& Environment, University of Southampton, Southampton, SO17 1BJ, UK

(E-mail: cjb@soton.ac.uk)

\begin{abstract}
An intermittent discharge waste stabilisation pond system was trialled for treatment of a seasonal wastewater load from a campsite. The system showed rapid acclimatisation to incoming load, with chlorophyll-a exceeding $700 \mathrm{mg} \mathrm{l}^{-1}$ within two weeks and filtered and unfiltered effluent biochemical oxygen demand below 20 and $30 \mathrm{mg} \mathrm{l}^{-1}$ respectively. Good performance continued for some weeks, after which photosynthetic oxygenation capacity in the first pond was seriously impaired by a shock loading believed to include fatty material. Inflow to the system was suspended and a surface film was broken up, after which the pond recovered within an 8-day period. Laboratory experiments indicated that interventions such as artificial aeration and dilution with effluent had no beneficial effect although mixing may have increased the rate of recovery.
\end{abstract}

Keywords: Waste stabilisation ponds; intermittent loading; facultative conditions.

\section{INTRODUCTION}

Intermittent or seasonally-increased wastewater flows arise in a number of situations, from popular holiday sites to accommodation for agricultural workers or refugees. The current research assessed the feasibility of using a waste stabilisation pond (WSP) system for treatment of a seasonal discharge of this type from a campsite at Lockerley Water Farm, Hampshire, UK. The site, owned by Hampshire Christian Trust, is used between June and September each year by up to 120 people a week. At other periods small groups occasionally use the site for meetings, parties or shorter camps. A range of facilities is provided including tents, mobile toilets and shower facilities, and a permanent kitchen block. Wastewater is collected in two underground storage tanks, and taken off site by tanker for treatment.

After an audit of water usage and wastewater generation, Boisseau (2005) concluded that an intermittent discharge WSP might provide an effective solution for on-site treatment. A single pilotscale pond was constructed, and was operated from July 2006 to July 2007 according to a typical mode for cold climate regions, where discharge is limited to a short period when the effluent quality is highest. This approach allows treatment of the load during summer, followed by an extended holding period during which algal populations are reduced, leaving clarified water for discharge. Whalley et al. (2012) monitored the performance of this pond and showed that although clarification did occur in winter, the system provided satisfactory treatment to meet discharge standards during the summer period. It was therefore concluded that the advantages of this operating mode were outweighed by the additional costs associated with the need to construct a pond large enough to store both the treated wastewater and any net incoming precipitation. 
A second pond was added in series with the first, and during the July - September 2007 camping season the system was operated to simulate continuous discharge of treated wastewater. The loading rate on the first pond in terms of 5-day biochemical oxygen demand $\left(\mathrm{BOD}_{5}\right)$ was about $130 \mathrm{~kg} \mathrm{ha}^{-1}$ day $^{-1}$, higher than the $80 \mathrm{~kg} \mathrm{ha}^{-1} \mathrm{day}^{-1}$ recommended for year-round UK operation (Mara, 2007); the second pond acted as a maturation/polishing stage. This operating protocol proved reasonably successful, although the first pond had low dissolved oxygen (DO) concentrations and a slight odour, indicating that the hydraulic retention time was too short (Whalley et al., 2011). Despite this the system performed well, with the two ponds producing an effluent of good quality.

The present research evaluated the performance with a reduced hydraulic loading on the first pond, and commencing with both ponds full of clarified water from the previous year, acting as a buffer to incoming load. During operation, however, an unexpected shock load modified the research direction to include consideration of recovery strategies based on laboratory-scale testing. To date there have been few studies on the impact of shock loadings on these systems, but recent studies are indicating the importance of loading rates in temperate climate systems (Abis and Mara, 2005; Faleschini et al., 2012)

\section{MATERIALS AND METHODS}

WSP layout and operation. Figure 1 shows the system layout. Wastewater from the campsite was received in Tank 1 and pumped in 128-litre batches 23 times a day into Pond 1. Pond 1 has a maximum water depth of $1.7 \mathrm{~m}$, and a capacity of $73 \mathrm{~m}^{3}$ giving a hydraulic retention time (HRT) of 25 days. Based on an average $\mathrm{BOD}_{5}$ of $200 \mathrm{mg} \mathrm{l}^{-1}$ for the settled wastewater, the design load on Pond 1 was $\sim 82 \mathrm{~kg} \mathrm{ha}^{-1}$ day $^{-1}$. Half of the effluent from Pond 1 was then pumped to Pond 2, with a maximum water depth of $1.3 \mathrm{~m}$ and a capacity of $30 \mathrm{~m}^{3}$, giving a 20-day HRT. Effluent from Pond 2 was pumped back to Tank 2 with the other half of the effluent from Pond 1, and then taken for off-site disposal. The system began operation on 28 July 2008, the first day of the main camping season, and wastewater was produced until the last camp closed on 5 September 2008.

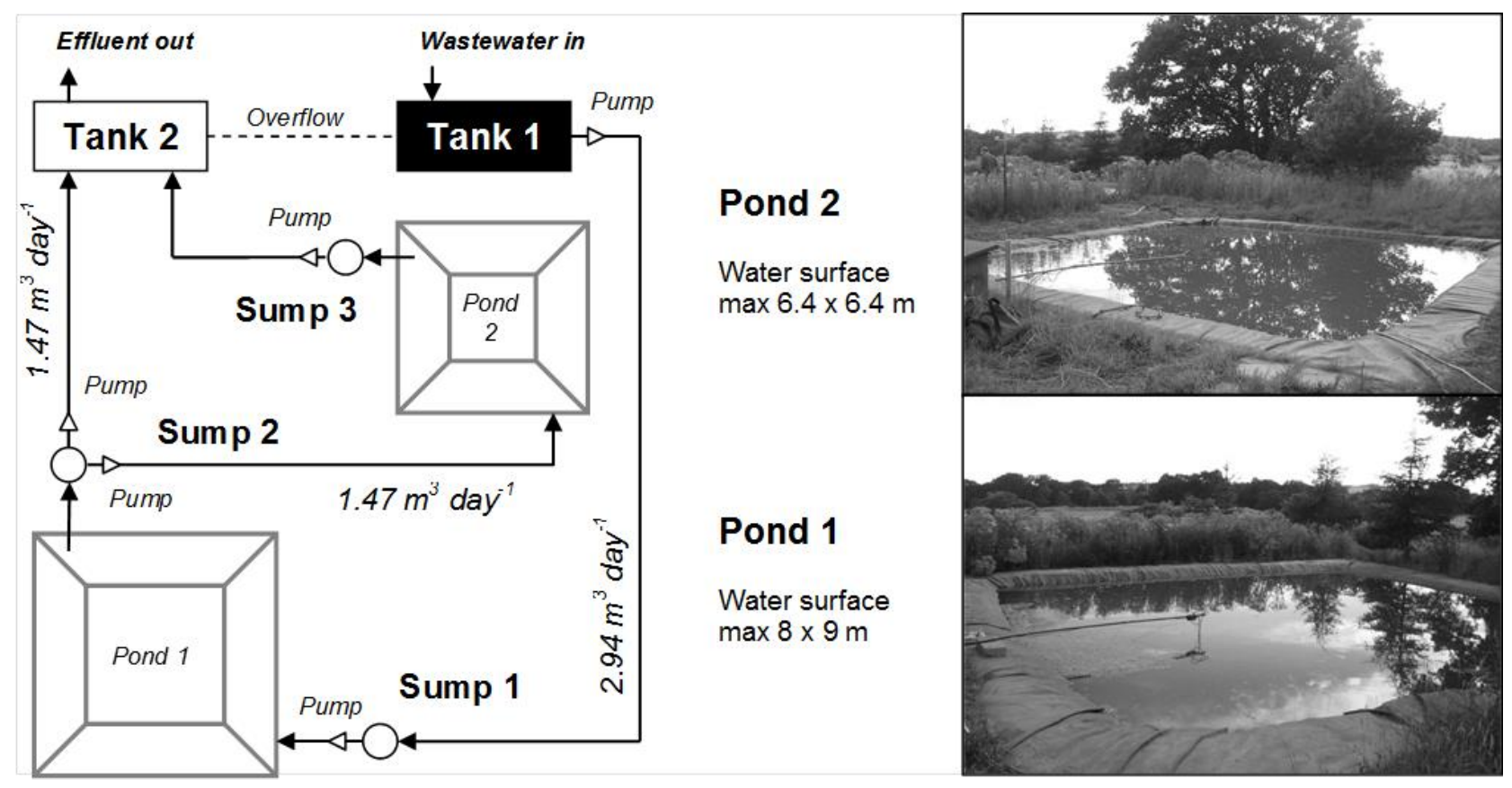

Figure 1. Schematic of site showing Ponds 1 and 2 
Sampling, monitoring and analysis. Each pond was instrumented with two DO probes, one $\sim 10 \mathrm{~cm}$ above the bottom and one near the surface. Data from these were recorded on a D500 datalogger (DataTaker, UK) averaged over 10-minute intervals. Air temperature and other climate parameters were recorded at 30-minute intervals by a WH-1080PC weatherstation (Wireless Pro, UK). Irradiance was measured by a RC/0308 photovoltaic cell (PV Systems, UK). On-site water consumption was recorded from the consumer meter provided by Southern Water Plc.

Influent wastewater and effluents from Ponds 1 and 2 were sampled twice weekly from 24 July. Chemical Oxygen Demand (COD), BOD 5 , suspended solids (SS), ammonia, nitrate and orthophosphate were measured by standard methods 5220 C, 5210 B, 2540 D, 4500-N B and 4500$\mathrm{P}$ E respectively (APHA, 2005). Conductivity as Total Dissolved Solids (TDS) was measured using a conductivity meter (Maplins Ltd, UK), and dissolved oxygen (DO) using a YSI 5000 meter (YSI, Yellow Springs, Ohio). Alkalinity was determined by titration with $0.25 \mathrm{~N} \mathrm{H}_{2} \mathrm{SO}_{4}$ to endpoint $\mathrm{pH}$ 4.0, using an automatic titrator (Titroline Easy, Schott, Germany), which was also used to measure $\mathrm{pH}$. Chlorophyll-a was measured by method $10200 \mathrm{H}$ (APHA, 2005), modified in that $\mathrm{MgCO}_{3}$ was added to the filter rather than acetone and the extract was not re-filtered after centrifuging. Absorbance was measured using a portable spectrophotometer (Hach, Germany).

Laboratory experiments to assess recovery potential were carried out by culturing pond samples in 2-litre flasks in a light box with 6 no. $30 \mathrm{~W}$ cool white fluorescent tubes. Three experimental flasks were set up, one of which was aerated, one seeded with water from Pond 2 in the ratio of the pond volumes (30:73), and the third mixed slowly without aeration. The flasks were sampled daily and monitored for $\mathrm{pH}$, DO, filtered and unfiltered COD and absorbance.

\section{RESULTS AND DISCUSSION}

The results of WSP monitoring are shown in Figure 2. Feeding Pond 1 with wastewater produced an immediate response in the form of an algal bloom, seen in the very rapid rise in chlorophyll-a, $\mathrm{SS}$, nutrient removal, and unfiltered $\mathrm{BOD}_{5}$ and $\mathrm{COD}\left(\mathrm{uBOD}_{5}\right.$ and $\mathrm{uCOD}$ ). This was expected to continue throughout the summer, but after three weeks conditions in Pond 1 changed: chlorophyll-a concentrations fell sharply, a surface film appeared and the water body became anoxic. Inflow to Pond 1 was stopped, and ways of recovering aerobic activity were investigated. Sampling from both Pond 1 and Pond 2 continued during the period of interrupted feeding to assess the natural recovery of Pond 1 and any maturation and polishing in Pond 2.

Air temperature and solar irradiance. Air temperature ranged from 8.2-31. $6^{\circ} \mathrm{C}$ with an average of $17.3^{\circ} \mathrm{C}$, close to the long-term average for the area. Maximum irradiance was $860.3 \mathrm{~W} \mathrm{~m}^{-2}$ on 14 August and the average was $139.7 \mathrm{~W} \mathrm{~m}^{-2}$. Conditions were thus suitable to support algal growth.

$C O D$ and $\mathrm{BOD}_{5}$. A spot sample taken on 6 August showed a sharp rise in influent organic strength, particularly uCOD. Concentrations remained high in three successive samples, before dropping to more typical values on 17 August, when the feed to Pond 1 was turned off. The high uCOD concentration was mirrored by rises in $\mathrm{uBOD}_{5}$ and in filtered $\mathrm{BOD}_{5}$ and $\mathrm{COD}\left(\mathrm{fBOD}_{5}\right.$ and fCOD), although to a lesser extent on the first and last two of these four sampling days.

A sharp rise in Pond $1 \mathrm{uCOD}$ was recorded in the sample taken on 14 August with a further rise on 18 August, at which point the pond was black in colour with a friable surface film. Similar, though smaller, rises were seen in fCOD and in $\mathrm{uBOD}_{5}$ and $\mathrm{fBOD}_{5}$. After feeding stopped the organic strength of the effluent fell during the following 10-day period. There was no apparent impact on Pond 2, as inflow to this pond stopped before the effect of the high load in Pond 1 was transmitted. 
Pond 2 effluent quality thus remained good throughout the summer with average $\mathrm{fBOD}_{5}$ and $\mathrm{uBOD}_{5}$ of 18 and $33 \mathrm{mg} \mathrm{l}^{-1}$ respectively.

Chlorophyll-a. Chlorophyll-a concentrations in Pond 1 were initially close to zero, as at the start of wastewater inflow the pond contained mainly rainwater collected over the preceding winter. The starting concentration in Pond 2 was $\sim 200 \mathrm{mg} \mathrm{l}^{-1}$, as this pond contained treated effluent from the previous year with a carry-over of algal inoculum. Algal growth in both ponds was rapid with chlorophyll-a in Pond 1 reaching $716 \mathrm{mg} \mathrm{l}^{-1}$ on 10 August, before falling to very low levels by 18 August. Concentrations recovered over the following 10 days, with a final peak as inoculum was added from Pond 2. Chlorophyll-a in Pond 2 remained around $430 \mathrm{mg} \mathrm{l}^{-1}$ until it was mixed with Pond 1 effluent on 27 August. This addition of nutrients resulted in a bloom, with chlorophyll-a concentrations reaching $712 \mathrm{mg}^{-1}$ by 4 September.
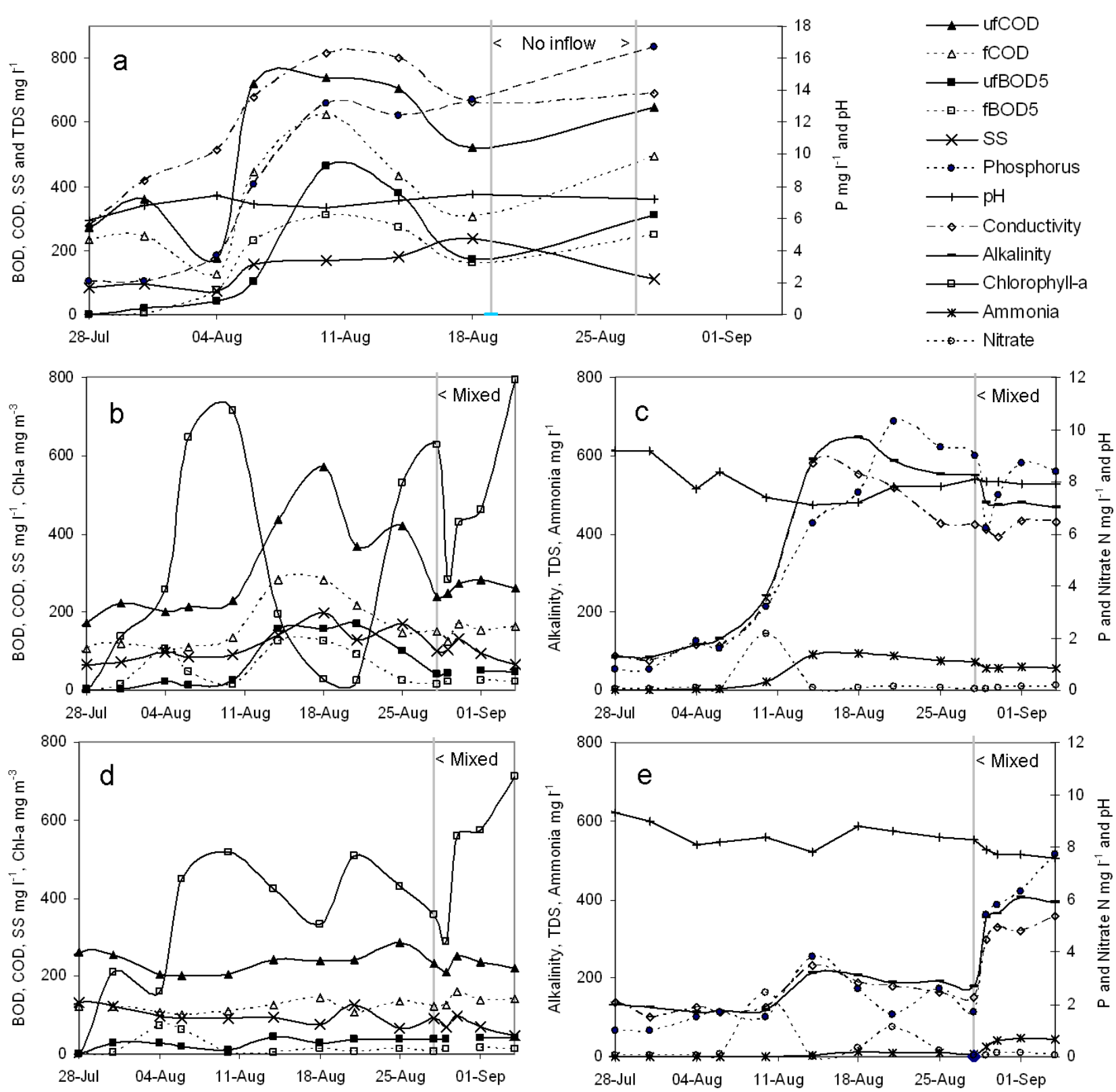

Figure 2. WSP monitoring results (a) influent COD, BOD, SS, pH, TDS and P; (b) Pond 1 COD, BOD, SS and Chlorophyll-a; (c) Pond 1 alkalinity, TDS and ammonia; (d) Pond 2 COD, BOD, SS and Chlorophyll-a; (e) Pond 2 alkalinity, TDS and ammonia. 
Dissolved oxygen. Initially DO followed the expected pattern, reaching supersaturation during the day with concentrations as high as $35 \mathrm{mg} \mathrm{l}^{-1}$. As the proportion of wastewater in Pond 1 increased, with its associated oxygen demand, there was a gradual reduction in the daily DO peak and at night oxygen deficiency occurred for short periods. Around the time the chlorophyll-a levels dropped and the pond became black, oxygen was deficient even during the day (Figure 3).

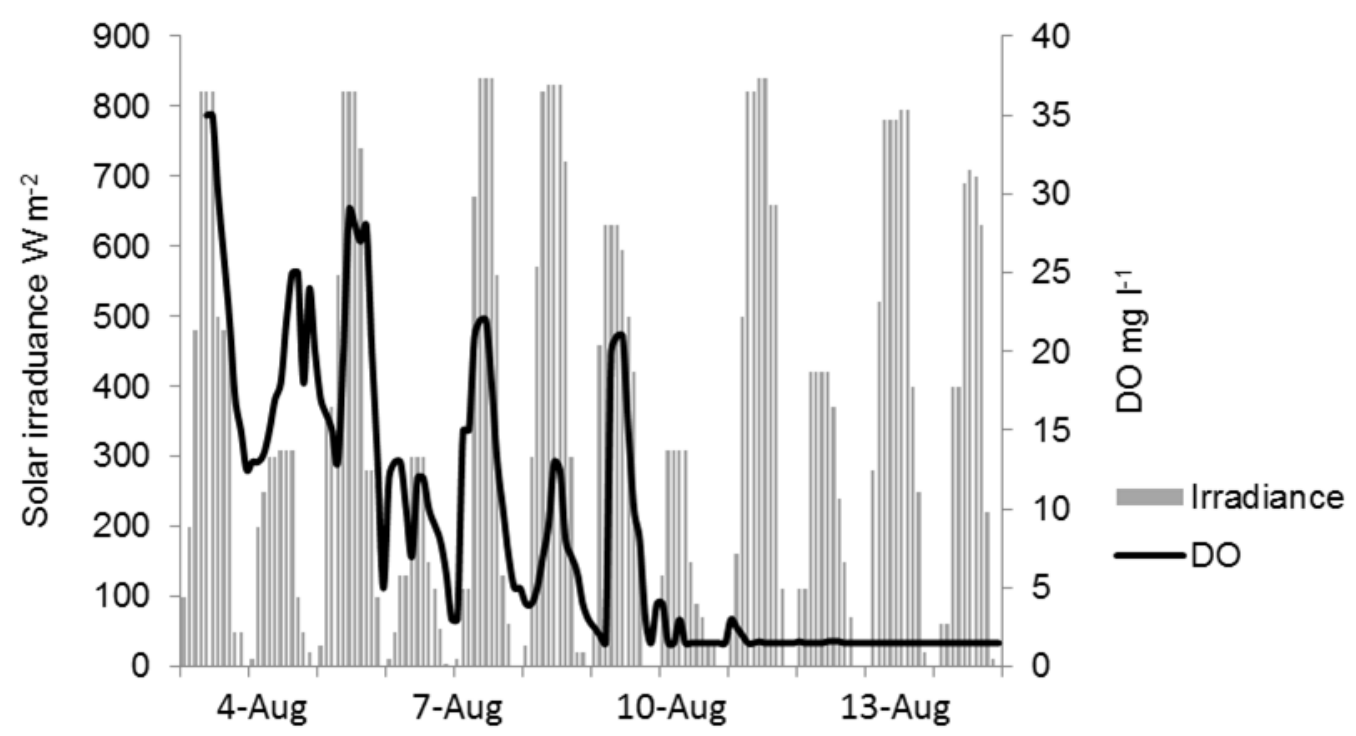

Figure 3. DO and irradiance in the shock loading period

Suspended solids. Increases in wastewater $\mathrm{uCOD}$ and $\mathrm{uBOD}_{5}$ were reflected in suspended solids, which rose to $236 \mathrm{mg} \mathrm{l}^{-1}$ by 18 August. SS in Pond 1 reached a peak around the time of maximum chlorophyll-a concentration. The fall in SS was not as dramatic as that in chlorophyll-a, however, indicating a change in the nature of the load from algal to wastewater solids. Pond 2 showed lower and more consistent SS concentrations averaging $92.5 \mathrm{mg} \mathrm{l}^{-1}$ (minimum 65 and maximum $133 \mathrm{mg} \mathrm{l}^{-}$ $\left.{ }^{1}\right)$, reflecting the more stable algal population.

Nutrients. The ammonia concentration in Pond 1 rose from 6 August, and by 17 August reached 91 $\mathrm{mg}^{-1}$. After wastewater addition ceased there was some reduction, possibly associated with the reappearance of algae. No nitrate was detected in Pond 1 and it is therefore unlikely that any ammonia oxidation took place. Ammonia could also have been lost through volatilisation, although during this period the $\mathrm{pH}$ of the pond was near neutral: recent studies have shown however that a number of factors are involved in ammonia removal and their interrelations are complex (Yamamoto et al, 2010; Faleschini et al., 2012). Ammonia in Pond 2 remained low (average $0.4 \mathrm{mg}$ $1^{-1}$ ) until about 10 August when the increasing nitrogen load in Pond 1 began to break through. When feeding was stopped on 18 August the ammonia concentration in Pond 2 had reached $13 \mathrm{mg}$ $1^{-1}$. The sudden increase to approximately $40 \mathrm{mg}^{-1}$ at the end of August reflects the higher concentration in Pond 1 as it was mixed with Pond 2 on 27 August. As expected, nitrate concentrations in the system were very low, and it was only during the period without feeding that levels of $1.12 \mathrm{mg} \mathrm{l}^{-1}$ were detected in Pond 2. Nitrification could possibly have occurred under the high dissolved oxygen conditions in the underloaded Pond 2 at this time (Valero et al., 2010).

Orthophosphate showed similar trends to those for ammonia, with concentrations in Pond 1 rising in response to increasing wastewater strength, except that the peak seen on 21 August did not occur until after wastewater inflow had stopped. It is possible that phosphate taken up by algae during the bloom was subsequently released back into the water body, at a time corresponding to the fall in 
chlorophyll-a concentration and changes in the visual appearance of the pond. Orthophosphate concentrations remained high during the period of interrupted feeding and Pond 2 again showed only limited breakthrough from Pond 1 until the two ponds were mixed.

Alkalinity and conductivity. Conductivity and alkalinity in the pond effluents remained low for the first three weeks, with closely matching values. As the influent alkalinity and conductivity rose, values in Pond 1 also rose, at a rate indicating that the pond was reasonably well mixed. By 17 August conductivity in Pond 1 was nearly equal to the influent value. After this, values for both parameters fell, with conductivity dropping more rapidly. Alkalinity and conductivity in Pond 2 increased only slightly before feeding was stopped, and remained low until the ponds were mixed. Values after 28 August indicated that mixing was effective, with differences between the two ponds of only $112 \mathrm{mg} \mathrm{l}^{-1} \mathrm{TDS}$ and $124 \mathrm{mg} \mathrm{l}^{-1} \mathrm{CaCO}_{3}$.

Flask experiments. Results of the flask experiments are shown in Figure 4. Filtered COD concentrations fell rapidly from initial values of 218,218 and $186 \mathrm{mg} \mathrm{l}^{-1}$ to 134,121 and $127 \mathrm{mg}^{-1}$ after one day in the stirred, aerated and mixed flasks respectively. After 4 days the fCOD in all three flasks stabilised at $\sim 120 \mathrm{mg} \mathrm{l}^{-1}$. Unfiltered COD in the stirred flask fell slightly on day 2 and 3 but then rose above its initial value, stabilising at $380 \mathrm{mg} \mathrm{l}^{-1}$ from days 5-7. In the aerated flask, on the other hand, uCOD dropped to $200 \mathrm{mg}^{-1}$ from day 1-5, apart from a peak on day 2; and only rose above $300 \mathrm{mg}^{-1}$ on day 6 and 7 . In the mixed flask, after falling for the first 2 days uCOD fluctuated around $300 \mathrm{mg}^{-1}$.

On day 1 the $\mathrm{pH}$ in the aerated flask had risen most, followed by the mixed flask, but over the next six days values in all flasks rose to between 9-9.5. High $\mathrm{pH}$ values are often observed in WSPs in daylight conditions, and reflect the absorption of $\mathrm{CO}_{2}$ from both community respiration and atmospheric sources for use in algal growth. Absorbance measurements for each of the flasks also reflected a rapid algal bloom. This occurred first and was most intense in the stirred flask, with absorbance values reaching 0.95 on day 7 . In the mixed and aerated flasks the increase began one day later, and by day 7 values had reached 0.75 and 0.70 respectively. DO concentrations were measured from day 3 and showed supersaturation at $\sim 14 \mathrm{mg} \mathrm{l}^{-1}$ in the stirred and mixed flasks, but only $9 \mathrm{mg}^{-1}$ in the aerated flask, possibly due to air-stripping of microbubbles. 

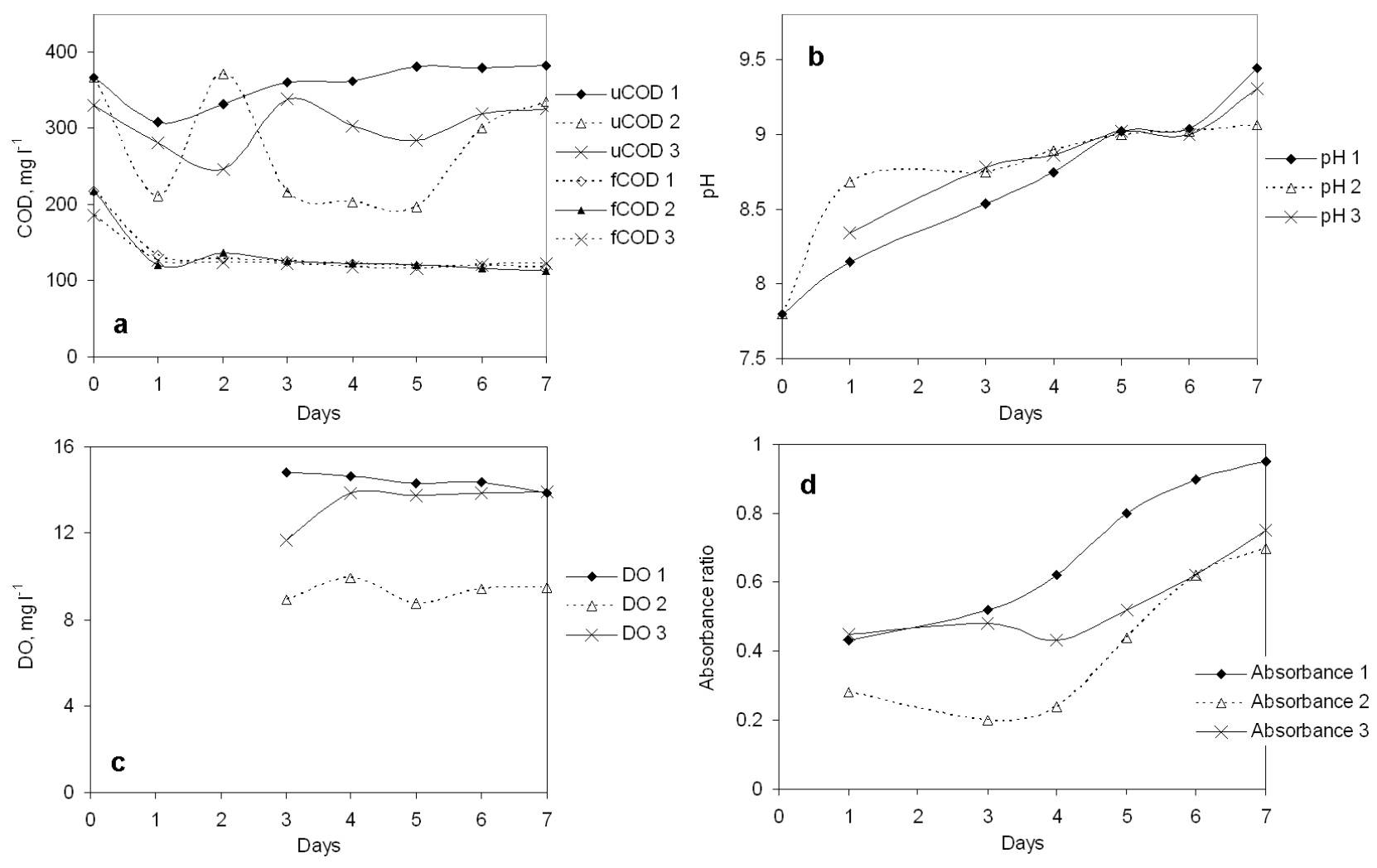

Figure 4. Results for flask testing of intervention strategies $(1=$ stirred, $2=$ aerated $3=$ mixed $)$. Filtered and unfiltered COD concentrations (a), pH (b), DO concentration (c), absorbance (d)

\section{Discussion}

With average wastewater flows of $5.59 \mathrm{~m}^{3}$ day $^{-1}$ and an average of 89 people on site each contributing $\sim 60 \mathrm{~g} \mathrm{BOD}_{5} \mathrm{day}^{-1}$, the expected $\mathrm{BOD}_{5}$ concentration of the raw wastewater is $955 \mathrm{mg}$ $1^{-1}$. The average influent $\mathrm{BOD}_{5}$ was $213 \mathrm{mg} \mathrm{l}^{-1}$. Sedimentation is normally considered to remove $\sim 40 \%$ of wastewater $\mathrm{BOD}_{5}$, while some $\mathrm{BOD}_{5}$ may be deposited off site e.g. during day-trips. The capacity of Tank 1 is $30 \mathrm{~m}^{3}$, however, giving an influent HRT of about 5 days. It seems likely that as well as allowing sedimentation Tank 1 provides some biological treatment, and part of the raw wastewater $\mathrm{BOD}_{5}$ is removed anaerobically. It is clear that Tank 1 is important to successful operation of the system, fulfilling the function of an anaerobic pond, although these are not normally provided in UK WSP systems (Mara, 2007).

System performance for the first three weeks after the start of the camp was excellent, with rapid rises in chlorophyll-a, high DO concentrations and low effluent $\mathrm{BOD}_{5}$ in both ponds. During this time chlorophyll-a in both ponds was above the $300 \mathrm{mg} \mathrm{m}^{-3}$ considered necessary to maintain stable facultative conditions (Pearson, 1996).

A loss of facultative conditions occurred in Pond 1 following the dramatic loss of chlorophyll-a in samples taken after 14 August. It is not clear what caused this upset, but its effect was clearly seen. The pond became black, with a thin surface layer of fatty material, and average DO concentrations fell almost to zero. Although influent $\mathrm{BOD}_{5}$ rose between 10-17 August, it is unlikely that the additional oxygen demand caused such a sudden catastrophic change. During this time there was no sign of a bloom in grazing fauna such as Daphnia which may cause a rapid reduction in algal numbers. Even when the net oxygen demand of the wastewater exceeds net algal oxygen 
productivity, pond failure is normally partial rather absolute, as oxygen production does not cease: the algae do not die, but simply fail to meet the demand exerted by the symbiotic algal-bacterial consortium. Lack of light causes a reduction in photosynthetic activity and, coupled with increased load, could cause algal die-off. Data for that period indicated, however, that solar irradiance was sufficient for algal photosynthesis and growth (Figure 3). The most probable explanation for the failure was the presence of the surface film which, although not analysed, appeared to be fat or oil. In these conditions mass transfer of gases is impeded and light transmission may also be affected, potentially leading to a reduction in algal numbers.

The cause of the surface film may have been a one-off incident, such as a discharge of cooking fats and oils to the drainage system rather than into the oil collection facilities provided on site. If this material entered Tank 1 it could have led to the sharp increase in fCOD noted after 4 August. As fats and oils may not be readily degradable in a typical 5-day BOD test, this could also account for the sudden increase in influent $\mathrm{COD}: \mathrm{BOD}_{5}$ ratio around this time, while the ratios of $\mathrm{uBOD}_{5}: \mathrm{fBOD}_{5}$ and uCOD:fCOD remained relatively stable.

A second possibility is that the incident was due to the design and operation of the collection system. The submersible pump feeding Pond 1 was suspended in Tank 1 at about half the tank depth. The proportion of wastewater that is not pumped to the ponds overflows from Tank 1 into Tank 2 by an interconnecting high-level pipe. Around the time of the failure it was noted that the level in Tank 2 was increasing. If this rose above the interconnecting pipe, the liquid level in Tank 1 would also rise. As the tank is a horizontal cylinder, this in turn would reduce the free surface area, creating a concentrated layer of floating fat and scum at the upper surface. When Tank 2 was subsequently emptied, a process taking only a few minutes with a suction tanker, the level in Tank 1 would drop rapidly to that of the interconnecting pipe, causing turbulence in Tank 1 . Concentrated oily scum could thus have been pumped to the pond at this time, around 10-14 August. Potential support for this explanation comes from the fact that a new emptying regime was introduced during this trial. In previous trials a level-switch in Tank 2 operated a signal to alert the camp manager that the tank would shortly need emptying. In the current trial this was changed to a regular schedule of tanker visits, with the result that emptying was less closely linked to the volume of wastewater produced, and maximum tank levels were more variable. In previous years some variation in the organic strength of the influent occurred on a week-to-week basis (Whalley et al., 2011 and 2012), but dramatic changes such as those in the current trial (Figure 2a) were not observed.

By 18 August Pond 1 was in very poor condition. The thin layer of visible surface contamination was broken up using a scraper, and drained off by reducing the outlet weir height. The influent flow was then turned off and the pond left to recover. It was expected that this would happen naturally, but the laboratory study was initiated to see if interventions could speed up the process. Chlorophyll-a concentrations in the ponds took about 8 days to climb back above $500 \mathrm{mg} \mathrm{l}^{-1}$; this happened more quickly under laboratory conditions in the flask experiments, giving an early indication that the problem was not due to an irrecoverable toxic shock.

Although Pond 1 appeared to be on its way to natural recovery it was decided to mix the contents of the two ponds on 27 August, one week before the camping season finished, to transfer some of the accumulated nutrient load into Pond 2. Eight days later, chlorophyll-a in both ponds exceeded 700 $\mathrm{mg} \mathrm{m}^{-3}$ and facultative conditions in Pond 1 had been completely recovered.

The research showed that the pond system responded very rapidly to the wastewater load applied at the beginning of the season. It also showed it was vulnerable to a shock load. This event was unexpected, and probably caused by the temporary nature of the feed system to Pond 1, and the 
need to return treated effluent to Tank 2 in order to comply with Environment Agency requirements not to discharge from the experimental ponds. The experience made it clear, however, that existing rules for separate collection of cooking fats and oils on the campsite may not be sufficient to prevent such problems occurring in a full-scale plant, and the final design must include a grease trap as an additional protection measure (Mara, 2007).

\section{CONCLUSIONS}

Start-up with both ponds full of treated and diluted wastewater allowed rapid algal growth in response to the commencement of wastewater inflow. Pond 1 also provided a degree of hydraulic buffering to Pond 2, as indicated by alkalinity and conductivity determinations and the appearance of free ammonia. High levels of dissolved oxygen could be maintained under normal loading conditions, reaching supersaturation during the day. The system was vulnerable to a shock input such as fatty or oily residues capable of coating the surface and reducing light penetration and/or mass transfer. Once the problem was removed the system was capable of recovery in a relatively short period without the need for further intervention. A laboratory study indicated that reinoculation or aeration did not stimulate recovery, and the main factor was probably increased light availability. The inlet storage tank plays an important role in treatment, and consideration must therefore be given to the design of the wastewater feed system to exclude fats and greases.

\section{REFERENCES}

Abis, K.L. \& Mara, D.D. (2005). Primary facultative ponds in the UK: the effect of hydraulic retention time and BOD loading on performance and algal populations. Water Science and Technology 51(12), 61-67.

APHA (2005) Standard Methods for the Examination of Water and Wastewater 21st ed. Washington DC: American Public Health Association.

Boisseau, R. (2005) Outline design solutions for low cost treatment of effluent from a campsite. MSc Thesis, School of Civil Engineering and Environment, University of Southampton, UK.

Faleschini, M, Esteves, J.L., Camargo Valero, M.A. (2012) The Effects of Hydraulic and Organic

Loadings on the Performance of a Full-Scale Facultative Pond in a Temperate Climate Region (Argentine Patagonia). Water Air Soil Pollut 223, 2483-2493.

Mara, D.D. (2007) Natural Wastewater Treatment. Chartered Institution of Water and Environmental Management, London.

Pearson, H.W. (1996) Expanding the horizons of pond technology and application in an environmentally conscious world. Water Science and Technology, 33 (7), 1-9.

Valero, M.A.C., Read, L.F., Mara, D.D., Newton, R.J., Curtis, T.P. and Davenport, R.J. (2010) Nitrification-denitrification in waste stabilisation ponds: a mechanism for permanent nitrogen removal in maturation ponds. Water Science and Technology, 61(5), 1137-1146.

Whalley, C.P., Heaven, S., Banks, C.J. and Salter A.M. (2012). Seasonally loaded waste stabilisation ponds: a novel application for intermittent discharge. Water Science and Technology, 66(9), 1893-1899.

Whalley, C.P., Heaven, S., Banks, C.J. and Salter A.M. (2011). Seasonally loaded waste stabilisation ponds: semi-continuous discharge from two ponds. 9th IWA Specialist Conference on Waste Stabilisation Ponds, Adelaide, 1-3 August 2011.

Yamamoto, A., Short, M.D., van den Akker, B., Cromar, N., Fallowfield, H.J. (2010) Nitrification potential in waste stabilisation ponds: comparison of a secondary and tertiary pond system. Water Science and Technology 61(3), 781-788. 